\title{
A Crossroad For Turkey: European Union Or Eurasian Economic Union
}

\author{
Ph.D. Candidate Nergiz Başeğmez (Beykent University, Turkey) \\ Asst. Prof. Dr. Kerem Toker (Beykent University, Turkey)
}

\begin{abstract}
With a long and complicated history with Turkey's EU relations began in 1963 with Ankara Agreement. Turkey has been engaged the full membership since 2005 but nevertheless it could not have achieved results during the negotiations. Behind the slow pace of Turkey's membership, many political and cultural barriers can be shown. The events showed that reveals Turkey cannot be an EU member as soon as possible. This case may cause the Turkey have different pursuits in the political world arena. Turkey moved away from the EU, it can be motivated to participate in different political and economic union at the same time. Because, the world is constantly changing in terms of economic and political conditions and Turkey is hard to question the position in these new conditions. Founded in 2015 Eurasian Union has similar cultural and historical heritage alongside the geographical closely EAEU with Turkey. This common history may create opportunities for both sides. In this study, economic, social and political relations between Turkey and the EAEU countries are briefly discussed. Datas about this issue were gathered by Eurostat, europa.eu, wto.org and eurasiancommission.org etc. official data sources. The findings were compared with similar indicators between Turkey and the EU. So the EAEU is evaluated likely to be an alternative political and economic union to Turkey. Such a vision changes in Turkey will revise its economic and political stability of the region. This paper may contribute to further studies by providing a solid base.
\end{abstract}

\section{Introduction}

Following the Second World War, Turkey choosed to take part in the Western Block and it applied to membership of European Economic Community after it was accepted the membership of North Atlantic Treaty Organization (NATO). This step would affect all subsequent decisions of Turkey (Uysal, 2001). In this way, Ankara Agreement between the European Economic Community and Turkey signed as the partnership agreement in 1963. This agreement predicted to three stages as "preparation," "transition" and "final" until it reaches full membership. Upon entry into force of the Ankara Agreement in 1964 began the preparatory phase ended with the Additional Protocol, signed in 1970 and began the transition phase. This phase ended with the signing of the Agreement on the European Customs Union in 1995. Thus, the hoped-for result of Turkey-European Union full membership in the relations "final" phase began (Demirkıran at all., 2010). With a long history in Turkey - EU relations represents the undulate but also important process for two sides. Despite all the tensions, both of sides never give up the other to date (Uysal, 2001).

It has also increased Turkey's expectations for full membership with the inclusion EU Customs Union (CU). However, some leading conservative European heads of government of Turkey's increasingly after the 1980 Europeans being stated that away. In particular, religious, geographical, because of problems related to human rights and Greece, which also difficult to be a full member of the Community indicated. A similar emphasis, particularly after 1980, also extensively discussed and processed in written and visual media in Europe. This negative development in Turkey has been the contribution of people who are refugees in Europe (Aslan, 2000). One of the big reasons of the European Union to refrain from pronouncing the date of full membership for Turkey to defer the risk of suddenly entering an irreversible process (Arsava, 2002). At this point, it would be appropriate to examine the contribution of the European Customs Union on the relationships between the Turkey - European Union.

Although Eurasian Economic Union is a young foundation, it provides a future with important expansions for Turkey due to geographical closeness to Turkey, common logistical networks, energy corridors and potential trade. Commercial partnerships with Eurasian Economic Union. Turkey will contribute an active power into EAEU with its existent economic and population potential. Cyclical negative relations between Russia and Turkey are assumed to get better in long term and both will need each other for the future of global world.

\section{European Customs Union and Turkey}

Today, the EU is the most advanced regional bloc which is stage of economic integration in the worlds. It has been implemented six expansionary phase until today and it has 28 member of EU. The EU reached the international economic forces, take part in these blocks has become attractive to other countries (Akçay, 2008). One of these countries is Turkey. Turkey as a member of the customs union in 1996 is the first step to be a part of this economic bloc. At the same time, Turkey has undergone a "Final Phase" pursuant to Ankara Agreement in partnership relations with the EU. Together with the Customs Union with Turkey is an important development affecting the entire economy, customs duties on trade in industrial products between the EU and Turkey, 
quantitative restrictions and measures having equivalent effect removed, Turkey has started to implement the Common Customs Tariff to third countries (Doğan and Kaya, 2011). It is very difficult to reach a definitive judgment by examining the Customs Union at the benefit-risk axis. But a number of studies examining the judgment and will lead to some statistics (AABBM, 2010). In the period after the Customs Union, Turkey's share in foreign trade in the EU While there wasn't a significant change, change in the composition of Turkey's exports it was observed. In particular, it has gained importance value-added and provider of high employment as white goods, automotive industry and competitiveness in the sectors has experienced positive developments (Doğan and Kaya, 2011).

\begin{tabular}{ccccc}
\hline Country Groups (1996) & Exports & Imports & $\begin{array}{c}\text { Balance of Foreign } \\
\text { Trade }\end{array}$ & $\begin{array}{c}\text { Proportion of Imports } \\
\text { Covered by Exports } \\
\text { (\%) }\end{array}$ \\
\hline Total & 23.224 .465 & 43.626 .642 & -20.402 .177 & 53,2 \\
\hline European Union (EU-28) & 12.590 .475 & 24.349 .181 & -11.758 .706 & 51,7 \\
\hline $\begin{array}{c}\text { Share of EU-15 in Total } \\
(\%)\end{array}$ & 54,2 & 55,8 & 57,6 & - \\
\hline
\end{tabular}

Table 1. Foreign Trades of Turkey at the Beginning of European Customs Union Source: Turkish Statistical Institute (TUIK), (2016)

Beginning in 1996, Turkey's foreign trade deficit began to grow rapidly with the EU. The average annual foreign trade deficit reached $\$ 10$ billion. The Turkish market is rapidly it became a EU 6th largest market in the world. The crisis of Turkey's manufacturing industry also largely depends on it. In return to Turkey's EU exports do not increase. Already textile industry is constitute $65 \%$ of Turkey's exports to the EU. Because the EU textile, are sourced from countries of the former Eastern European countries and established a special relationship countries such as China and India (Doğan, 2004). Turkey, while exports to consumer goods such as textile, clothing and food products to EU, mainly from the EU chemical, intermediate and investment goods such as machines and vehicles, iron and steel products are imported. This means that about half of the import and export amount of Turkey is dependent on the EU economy (Aktaş ve Güven, 2003).

\begin{tabular}{ccccc}
\hline Country Groups (2015) & Exports & Imports & $\begin{array}{c}\text { Balance of } \\
\text { Foreign Trade }\end{array}$ & $\begin{array}{c}\text { Proportion of } \\
\text { Imports Covered by } \\
\text { Exports (\%) }\end{array}$ \\
\hline Total & 143.861 .522 & 207.206 .813 & -63.345 .291 & 69,4 \\
\hline $\begin{array}{c}\text { European Union (EU- } \\
\mathbf{2 8})\end{array}$ & 64.003 .582 & 78.668 .777 & -14.665 .195 & -3 \\
\hline $\begin{array}{c}\text { Share of EU-28 in Total } \\
(\%)\end{array}$ & 44,4 & 37,9 & 23,1 & - \\
\hline
\end{tabular}

Table 2. Foreign Trades of Turkey with European Union (Thousand \$) Source: Turkish Statistical Institute (TUIK), (2016)

As shown in Table 2, almost half of Turkey's total foreign trade volume is carried out by the EU. The main reason of commercial concentration between the EU and Turkey; it is the cultural and geographical closeness. Customs Union has contributed to the establishment of economic closeness between the parties (Özsan, 2015).

However it did not come from the EU capital for investment, even decreased. EU companies of Turkey to the EU would open all doors to goods sent to Turkey instead build factories in Turkey. In fact, they get produced goods to cheaper third countries and after deal to Turkey. Therefore, investment from Europe declined since 1996. Foreign capital is generally invested in that country to overcome the wall when there tariff barriers. This capital has gone to China because of customs barriers (Özsan, 2015). Therefore, it is difficult to say that Turkey expects to find from customs union agreement.

\section{Demographic Structure of EU and Turkey}

Population and development relationship is an issue that always focus on countries. Because the population is an important element in providing labor required for development on the one hand; the other hand, excessive population growth is slowing down the development besides an issue that may cause a reduction in per capita income and various problems (Şahin, 2008). Labor force is an indicator of human element in the economic activity. 


\begin{tabular}{|c|c|c|c|c|}
\hline \multicolumn{3}{|c|}{ European Union (EU-28) } & \multicolumn{2}{|c|}{ Turkey } \\
\hline \multicolumn{3}{|c|}{508.450 .856} & \multicolumn{2}{|c|}{77.695 .904} \\
\hline \multicolumn{3}{|c|}{ Years } & \multicolumn{2}{|c|}{ Years } \\
\hline $0-14$ & $15-64$ & $65+$ & $0-14$ & $65+$ \\
\hline$\% 15,6$ & $\% 65,9$ & $\% 18,5$ & $\% 24,6$ & $\% 7,7$ \\
\hline
\end{tabular}

Table 3. The Population Structures of EU and Turkey Source: Eurostat, (2016)

In addition to these problems, the most serious problem for the European Union is the decrease of young population and the decrease of old age population. As population aging in European Union causes various problems, the decline of working capacity and fertility becomes at the head of the problems. While looking the estimations for the years between 2020 and 2025 it is said that old age population rate will pass over young population rate in European Union. Accordingly, the need for labor force will increase within the decrease of fertility (Şen, 2014). In contrast with young population structure of Turkey, it is seen that the population of European Union is old and aging process maintains. European Union may benefit from the young population of Turkey in the policies about the protection of producing power. However, despite of the high young population rate in Turkey, the lacks in education and quality of this population make the adaptation to the employment process in European Union difficult.

When the population of European Union countries have decreased, Turkey has attracted all the attentions due to the increase of Turkish population and the highest migration tendency as 6,2 percent among the candidates for European Union. In view of young and employed population; within the membership of Turkey into European Union migration to Turkey may cause positive impact for European Union due to the free circulation of labor force as a data. On the other side, because the number of qualified employee will begin to decrease, the high rate for the migration tendency of many individuals in Turkey is a positive development for European Union. Within the context of Turkey's membership to European Union, it is estimated that more than 2,7 million people will migrate in the common result for the works in order to evaluate possible migration movements (Şen, 2014).

\section{Eurasian Economic Union}

Regional economic integration is a noticeable trend in the global economy, whose future, probably, will largely depend on the effectiveness of global dialogue of integrational entities and on their internal stability. Eurasian Economic Union (EAEU) which laid the foundations with a treaty among the leaders of Belarus, Kazakhstan and Russia on 29 May 2014 with Armenian involvement on 9 October 2014 was officially founded on 1 January 2015. Kirghizstan took a decision for the membership on 11 April 2011 and officially became the member on 8 May 2015 in Russia’s capital city Moscow (Sülün, 2015). In this way Eurasian Economic Union has consisted of five countries as Belarus, Kazakhstan, Russia, Armenia and Kirghizstan. The Union has 182,1 million people as a population and 2,411,2 billion dollar as Gross Domestic Product (GDP). At the same time Eurasian Economic Union has executed industry production valuing 1,3 trillion dollar (eurasiancommission.org, 2015). On the other side, the Union has signed "Free Trade Agreement" with some countries. The first draft agreement was confirmed by Russian government on 25 May 2015 for the foundation of free trade area between Eurasian Economic Union and Vietnam. Eurasian Economic Union has aimed to enhance its economic hinterland by signing free trade agreement with Egypt in the next months. Besides, it is expected that Central Asian countries such as Uzbekistan, Tajikistan and Turkmenistan and some countries such as Azerbaijan and Ukraine will play a part in Eurasian Economic Union in the forthcoming days (İncekara ve İncekara B., 2015).

It is difficult to forecast that Eurasian Economic Union which began with Customs Union Agreement will transform into either political integration or not. In addition to this, Eurasian Economic Union has aimed integration in plenty of field from the food sector to energy. For example, Nazarbayev suggested to constitute a Common Technical Area in the region. A common electric network has also been at issue. Moreover, each side has been in search of solving food problems in the region (İşyar, 2012). To provide economic union as a common goal has become clear with notably targets and all the movements in concrete economic field by straitening the frame rather looking after political interests as an ultimate goal in the foundation of the Union. The main basis of integration is economy (Bahtiyar, 2015). In line with these developments, Turkey has continued to enlarge and deepen its existent historical links with Eurasian Economic Union countries down from long years.

\subsection{The Economic Relations between Turkey and Armenia}

While evaluating the economic relations between Turkey and Eurasian Economic Union, the matter has become more complicated. It is possible to say that Eurasian Economic Union Project has had an important position for Turkish foreign policy. However, Turkey which recognized first the independence of Armenia among the other countries after the disintegration of the Soviet Union closed border gate with Armenia in 1993 as its Azerbaijan policy and took a decision laying an economic embargo to Armenia. But the trade between Turkey and Armenia 
has gone on proceed by the way of largely Georgia and Iran. Today the use of Turkish construction materials in the buildings of Armenia and Turkish products in workplaces and general stores are seen by naked by without indepth research. Despite inclose borders, trading volume between two sides was 4,5 million dollar in 1993, scaled up 30 million dollar in 1997, 120 million dollar in 2007 and has been 200 million dollar since 2008 (Ozinian, 2013). This situation indicates the need of steps for the normalization of commercial relation policies between Turkey and Armenia.

Accordingly; within the frame of a will about the normalization of relations and overcome the problems between Armenia and Turkey, the process beginning in 2007 with the mediatorship of Switzerland entered to a new process with "The Protocol of Setting Diplomatic Relations" and "The Protocol for Developing Bilateral Relations" (Bahtiyar, 2015). Despite of all well-disposed attempts between these two Armenia and Turkey, recognition process of the protocols were ceased by both countries.

\subsection{The Economic Relations between Turkey and Russia}

Russia has been the biggest and the most important neighbor and the most serious competitor of Turkey in immediate environment at least for 250 years. Today the two biggest economic and military power from GermanyItaly to China-Iincekarandia border in wide Central Eurasia Area is undoubtedly Russia and Turkey. This condition has led to witnessing many conflicts, competitions and wars in Turkish-Russian relations in all the periods of history (Zengin, 2015). Both Russian Federation and the old Union of Soviet Socialist Republics (U.S.S.R.) are one of the important trading partners of Turkey. Since the beginning of 1990's Russia has had a fluctuated structure in commercial relations. Balance of trade between these countries is against Turkey (Duman ve Samadov, 2003). In the recent period, there has been economic and commercial matters consisting of energy and defense industry at the center of relations between the two countries (Çelikpala, 2015).

While Turkey has mostly exported to European Union countries, it has also mostly imported from Russia which is one of the countries of Eurasian Economic Union. Namely, the maximum export share in Turkish foreign trade has respectively belonged to Germany, England, Italy and France among the European Union countries. Turkey has mostly had export with Germany and this export has been almost 13,96 billion dollar since 2011. While the datas are examining in terms of import, it is seen that Turkey's import has respectively been with Russian Federation, Germany, China and U.S.A. (Zengin, 2015). In 2013 Aleksandr Lukasevic- the spokesman Russian Foreign Ministry stated that Russia composed 9,3 percent in share of total foreign trade in Turkish Republic and trading volume between two countries in 2012 increased than the previous year and reached 34,3 billion dollar (Demir, 2014).

Turkey and Russian Federation have a mutually complementary structure in terms of economic and commercial relations. Turkey's services export such as consumer products and the construction business, entertainment of Russian tourists, purchase of semi-manufactured products, petrol, natural gas and coal seem to verify this diagnosis (Zengin, 2015). Russia has reached the condition of a broad market in fresh fruit, vegetable, chocolate, biscuit, macaroni, tobacco, liquor, non-alcoholic drink, vegetable oil, tea, textile, ready wear, personel auto, electronic item, white goods and many other products which are known as fragile goods in West market and are produced by Turkey. The visible rise in making these products in Turkey has partially actualized with demand increase in Russian market.

\subsection{The Economic Relations between Turkey and Kazakhstan}

In the evaluation of economic relations between Turkey and Kazakhstan, primarily building trade should be regarded. Building trade of Kazakhstan has a high rate as 6,6 percent in GDP. This is one of the foremost sectors for the country and Turkey has an important place in terms of investments to the country with the steps for building trade (Başç1, 2015). Thus, after the independence of Kazakhstan, Turkish private sector has strongly fronted to get in contact with the region. Also, the concentration in the field of construction business has been seen. These companies has a comparative superiority in many respects in comparison to other international companies competing for similar works. The reasons of this situation are that the business is large-scaled and quality according to Central Asian criteria, the prices are comparatively low and the companies are open to various payment kinds (Dikkaya ve Bora, 2006).

While analyzing commercial relations between Turkey and Kazakhstan, it can be thought that there is a considerable level of these relations. Turkey has had commercial relations with approximately 220 countries. While analyzing exports with these countries, it is observed that Kazakhstan has an array between 29 and 37 during the years between 2005 and 2015. In import this array is between 21 and 37. From 2005 to 2012 a continuous increase in trading volume except crisis years is observed. After 2012, there has been a decrease. Equilibrium datas indicates the remarkable point that the import of Turkey to Kazakhstan is higher than export to the same country (Başç1, 2015). Commercial relations between two countries show that Turkey has a potential for being strategic partner of Kazakhstan by developing cooperation in Eurasia with the impacts of their common history, common ethnicity and common cultural features. At the same time, Turkey is candidate for being important market with its ever-growing industry, increasing consumption expenditures and growing export potentials (Dikkaya ve Bora, 
2006). Especially the importance of economic intimacy with Kazakhstan has increased whereas Turkey's foreigndependent energy policies.

\subsection{The Economic Relations between Turkey and Belarus}

Belarus is 68th in world economy with its 76,1 billion dollar GDP according to datas of World Bank 2014 Report (worldbank, 2016). Turkey was the first country recognizing the independence of Belarus and diplomatic relations began on March 25, 1992. The relations between two countries has proceeded at a positive course (mfa.gov.tr, 2016). Turkey has adopted constructive policy because providing common ground and interests with international society will develop the dialogue and cooperation with the European-Atlantic institutions and provide both regional peace and stability and national interest of Belarus (Bahtiyar, 2015). In total investments to Belarus, Turkey has been one of the first five countries with 1,1 billion dollars. Turkish entrepreneurs has put important projects into practice and total value has reached 900 million dollars. Bilateral trading volume which is at humble level as being 379 million dollars by year 2014 on November is aimed to keep up 1 billion dollars in the upcoming years. Besides, Turkey has had presidentship of Working Group from 2010 about participation of Belarus in World Trade Organization. In 2014, the number of tourists from Belarus to Turkey increased 10 percent and surpassed 220 thousand. The visa-free travel regime coming into force on June 2014 indicates the positive contribution to Turkey's human relations. The positive commercial and human relations between these two countries for years give hope to bigger economic developments.

\subsection{The Economic Relations between Turkey and Kirghizstan}

Despite of being a small country, Kirghizstan has had a great effort in order to be integrated into world trade. The country has amended and made some comprehensive regulations as a reform in order to develop economically. Foreign trade regulation has considerably been liberalized. In this context, extraverted economy policy has been adopted. The country has made some institutional arrangements to be integrated into world economy without any dependency to Russia (İnançlı at all., 2015).

The relations between Turkey and Kirghizstan has followed a positive course in strategic partnership level with mutual strong will. Turkey has supported the institutionalization of Kirghizstan with its all state-owned companies and non-governmental organizations. Multidimensional relations in the field of policy, economy, trade, military, culture, education, health and transportation has maintained within the scope of a broad legal basis containing more than 200 hundred agreements and protocols. Turkey has exported jewelry and its sections, textile products, woven carpets, personal cleaning products, cacao- free sugary products, electric waterheaters, electrothermic devices, space heaters, blow dryers and iron. Besides that Turkey imported from Kirghizstan legume, cotton, copper scraps, canned vegetables, aluminum scraps, gold, fresh and dried fruits, unfinished bullet and aluminum. About 300 Turkish capital companies carrying on various sectors have contributed Kirgiz economy with 304 million dollars capital and have employed more than five thousand Kirgiz citizens. On the other side, 163 company with Kirgiz capital has been active by year 2015 on December. Up to now, Turkish contracting companies has undertaken 65 projects valuing 689 million dollars (mfa.gov.tr, 2016). Commercial relations between two countries has widened from year to year.

The main documents of strategic partnership between two countries are "Agreement of Perpetual Friendship and Cooperation" signed in 1997 by both the presidents of Turkey and Kirgizstan, the assertion as "Turkey and Kirgizstan: to 21 st century together" published in 1997 and "Common Statement about the Foundation of HighLevel Strategic Partnership Cooperation" signed in 2011. There has been no problem in political relations between Turkey and Kirghizstan and in multilateral plan Kirgiz administration has supported and played a part in formations as in Turkish Council (Bahtiyar, 2015). In relevant term, the average export to Kirghizstan has composed of 7,84 percent investment goods, 29,53 percent raw materials, 62,11 percent consumer goods and 0,52 percent other product groups. The average import from Kirghizstan has composed of 0,86 investment goods, 42,67 percent raw materials, 56,46 percent consumer goods and 0,02 percent other product groups (İnançlı at all., 2015).

\section{The Relations between Turkey and Eurasian Economic Union}

Turkey has always a role in the Eurasian Economic Union region with the impact of historic links. After the Second World War, Turkey pursued a west- sided foreign policy containing United States of America and European Union. However, the country has had an observable understanding that other regions of the world have been seen (İncekara ve İncekara B., 2015). There are geopolitical, economic, political and even sociologic features of Turkey in a possible membership to Eurasian Economic Union. Geopolitically, within the membership of Turkey new geopolitical and trade routes will open. The membership of Turkey means that Eurasian Economic Union can go down to the Middle East and Mediterranean. Russia can find the opportunity to reach Eastern Europe by way of Belarus and Turkistan and the Far Asia by way of Kazakhstan. For Turkey, the membership of Union is an opportunity to reach the South. This means that the membership will obtain the opening of new trade routes. One of the most important routes is the Black Sea region putting to sea as a unique direction for the Union. Thus, Black Sea region can be duty- free entrance door for coming products (Hazir, 2015). 


\begin{tabular}{ccccc}
\hline Country Groups (2015) & Exports & Imports & $\begin{array}{c}\text { Balance of } \\
\text { Foreign Trade }\end{array}$ & $\begin{array}{c}\text { Proportion of } \\
\text { Imports Covered by } \\
\text { Exports (\%) }\end{array}$ \\
\hline $\begin{array}{c}\text { Total of Turkey } \\
\begin{array}{c}\text { Eurasian Economic Union } \\
(\text { EAEU -5) }\end{array}\end{array}$ & 143.861 .522 & 207.206 .813 & -63.345 .291 & 69,4 \\
\hline $\begin{array}{c}\text { Share of EAEU-5 in Total } \\
(\%)\end{array}$ & 6,7 & 21.780 .315 & -12.101 .381 & 44,4 \\
\hline
\end{tabular}

Table 4. Foreign Trades of Turkey with Eurasian Economic Union (Thousand \$) Source: Turkish Statistical Institute (TUIK), (2016)

Commercially, Eurasian Economic Union countries are the first in petrol and natural gas production all around the world. These countries have 183 million population and 2,7 trillion dollars economic volume. Turkey may be an important country in the supply the needs of millions of people. Turkey is also an important country in contributing market economy of Eurasian Economic Union. Turkey can reach Turkistan through Caucasus and in this way the productions of Kazakhstan can easily reach to Turkey (Hazır, 2015). In addition to this, the common market is seen as decennary goal without legislation barriers in the production of energy, petrol and petroleum product over Eurasian region (İncekara ve İncekara B., 2015). Under these circumstances, Turkey which has been foreign- dependent in energy may be advantageous for the Union.

\section{Demographic Structure of EAEU and Turkey}

Eurasian Economic Union has composed a common labour market in order to provide a dynamic structure for the population movement. Now, ordinary citizens of each member state can easily get a job in other member state without getting work permit and foreign workers quota. The obligation for the registration to Police Department for workers and their families in the relevant region has been cancelled. Down to 30 days they can stay as unregistered. In addition to this, since 2015 on January 1 university diplomas of the member states are automatically recognized in other member states (Bahtiyar, 2015).

\begin{tabular}{cccccc}
\hline \multicolumn{2}{c}{ Euroasia Economic Union (EAEU-5) } & \multicolumn{3}{c}{ Turkey } \\
\hline \multicolumn{3}{c}{183.319 .693} & & Years & \\
\hline $0-14$ & Years & & 095.904 & \\
\hline$\% 21,9$ & $15-64$ & $65+$ & $0-14$ & $15-64$ & $65+$ \\
\hline
\end{tabular}

Table 5. The Population Structures of EAEU and Turkey Source: http://www.un.org/ (2016)

As seen at above table 5, population structures of both Turkey and Eurasian Economic Union shows a similar characteristic. This situation may provide an opportunity to improve positive policies in terms of market opportunities and mutual mobility of the work force. While 0-14 group of age in Eurasian Economic Union has 21,9 percent share in total population, this rate in Turkey is 24,6 percent. The rate of old age population $(+65)$ is 9,8 percent in EAEU and 7,7 in Turkey. The potential membership of Turkey into EAEU will create a positive impact in terms of youthening of the Union population.

\section{Conclusion}

Meanwhile, the success of the negotiation process for candidates to circumvent the country is instantly opening the way to full membership. Because Turkish people was formed such a belief. Even the very difficult negotiation process completes, Turkey won't immediately open the way for full membership. So in the end the success of the negotiations does not guarantee membership. If the negotiations end with success in Turkey can be vetoed by a member country. For example; England, despite the period to complete the negotiations, France had been vetoed twice by President Charles de Gaulle in 1963 and 1967. England, the French referendum in 1972 could enter the EU (Özer, 2009). In addition to this, young and purchasing power of the population of Turkey is an important market for EU countries. Indeed, it is quite difficult to sell to many industrial products produced to different less developed countries. Therefore, the population of Turkey is an important market potential for EU countries. In addition, Turkey's population provides cheap labor to EU despite aging population of the EU countries (Şahin, 2008).

Full membership of Turkey into European Union is more preferable than Customs Union. Because, with the full membership the advantages and disadvantages of the Customs Union will realize in any case. However, the full membership will bring Turkey many aids and credits of the European Union, provide stability in social security, money and budget policies, reform democracy and complete integrations with western countries. On the other 
hand, the full membership will guarantee the free circulation of labor force (Yalçınkaya at all., 2009). Thus, obvious discourses and concrete calendars are necessary to reveal the full membership of Turkey for European Union.

Having said that, Turkey is still NATO member. For this reason, it is not possible for Turkey to move off western block in the short term. European Union countries has 50 percent share in trading volume. There is also Customs Union Agreement with Europe. This agreement can be seen as obstacle for the entrance to EAEU of Turkey; but it must be noted that this agreement is on behalf of Europe and may damage Turkish economy. Because Turkey is directly affected by agreements of European Union with third parties. At the same time, full membership of Turkey into European Union appears impossible for now. Turkey doesn't have in mind to wait at the European Union gate. Consequently the country wants to evaluate many alternatives. In this context, Eurasian Economic Union is significant for the future vision of Turkey (Hazır, 2015). Another significant point is the necessity for the termination of European Customs Union Agreement with Turkey which wants to enter Eurasian Economic Union. As current Ankara Treaty and Additional Protocol doesn't change, Turkey cannot exist in two different customs union in compliance with World Trade Organization and General Agreement on Tariffs and Trade (Karluk,2015).

On the other hand, Turkey' EAEU membership is not only disengagement of U.C. but also cause tension between U.S.A. and Turkey. In terms of balance of foreign policy for Turkey, EAEU membership means a radical disengagement of West. Psychological reason of this disengagement is that Turkey has been faithfully kept to westernization vision but Turkey could not see the same sensitiveness. In Turkey, economical rota alteration can assist to the Far East bazaar which is becoming richer with EAEU. For instance, EAEU membership can be a step to Shangai Cooperation Organization. All the same this economical potential and strategic alternative are evaluated, it can be say that Turkey has a potential to create a lot of occasion for future economical world. But it is very important that a long term national decree, which can be evaluate these occasions, for different economical and political strategies.

\section{References}

- Akçay, 2008. “Avrupa Birliği’nin Ekonomik Kriterleri ve Türkiye”, Maliye Dergisi, Vol:155, p. 11-38.

- $\quad$ Aktaş and Güven, 2003. "Gümrük Birliği Sonrasında Türkiye'nin İthalat Fonksiyonu Katsayılarındaki Değişimin İncelenmesi”, Dumlupınar Üniversitesi Sosyal Bilimler Dergisi, Vol:9, p. 67-80.

- Antalya AB Bilgi Merkezi Raporu, 2010. “Gümrük Birliği’nin Türk Ekonomisine Etkileri”, p. 1-11.

- Arsava, 2002. Kopenhag Zirvesi Işı̆̆ında Türkiye - AB İlişkileri, Rekabet Kurumu Perşembe Konferansları, Aralık, p. 1-6.

- Aslan, 2000. “Türkiye-Avrupa Birliği: Sancılı Gelişen İlişki”, Ankara Üniversitesi SBF Dergisi, Vol:55(3), p.1-20.

- Bahtiyar, 2015. “Türkiye Ve Ab’nin Avrasya Ekonomik Birliğiyle Tarımsal Ürün Ticareti Üzerine Analiz”, Gıda Tarım Ve Hayvancılık Bakanlığg Avrupa Birliği ve Dış İlişkiler Genel Müdürlüğü AB Uzmanlık Tezi, Ankara.

- C Çelikpala, 2015. "Rekabet ve İşbirliği İkileminde Yönünü Arayan Türk-Rus İlişkileri”, Bilig, Vol:72, p. 117144.

- Demir, 2014. "Tarihsel Perspektif Işı̆̆ında Türkiye Cumhuriyeti ve Rusya Federasyonu Arasındaki İlişkiler”, Yönetim ve Ekonomi, Vol:21(2), p. 179-197.

- Demirkıran, Çiçek, Eltetik, and Sarıkçıŏglu, 2010. Türkiye-Avrupa Birliği İlişkilerinde "Son Dönem”, Niğde Üniversitesi İIBF Dergisi, Vol:3(1), p. 57-75.

- Dikkaya and Bora, 2006. “Çăgdaş Kazakistan’ın Ekonomi Politiği Ve Türkiye'nin Yeri Türkiye'nin Yeri”, $O A K A$, Vol:1(2), p. 110-127.

- Doğan, 2004. “On Yıllık Dönemde Gümrük Birliği’nin Etkileri Ve Sonuçları Üzerine Bir Değerlendirme”, Mevzuat Dergisi, Vol:79, p. 1-12.

- Doğan and Kaya, 2011. “Gümrük Birliği Sonrasında (1996-2009) Türkiye’nin Avrupa Birliği İle D1ş Ticaretinin Ülke Ve Fasıl Bazlı Yoğunlaşma Analizi”, Ekonometri ve İstatistik, Vol:14, p.1-18.

- Duman and Samadov, 2003. "Türkiye ile Rusya Federasyonu Arasındaki İktisadi ve Ticari İlişkilerin Yapısı Üzerine Bir İnceleme”, Kocaeli Üniversitesi Sosyal Bilimler Enstitüsü Dergisi, Vol:(6), p. 25-47.

- Eurasian Economic Integration: Facts And Figures, 2015. http://www.eurasiancommission.org/en/Documents/broshura26_ENGL_2014.pdf

- Eurostat, Population Data, 2016. http://ec.europa.eu/eurostat/web/population-demography-migrationprojections/population-data

- Hazır, 2015. Türkiye’nin Avrasya Ekonomik Birliği’ne Üyeliği Mümkün mü?, Akademik Perspektif. 
- IInançlı, Konak and Ashimova, 2015. "Türkiye-Kırgızistan Ekonomik İlişkilerinin Dış Ticaret Üzerine Yapısal Ve Sektörel Olarak Yansımaları”, Kastamonu Üniversitesi İktisadi ve İdari Bilimler Fakültesi Dergisi, Vol:8, p. 111-124.

- IIncekara and İncekara, 2015. “Avrasya Ekonomik Birliği Ve Politik Ekonomik Etkileri”, Nişantaşı Üniversitesi Sosyal Bilimler Dergisi, Vol: 3(1), p. 111-129.

- İşyar, 2012. “Avrasya’daki Güncel Gelişmelerin Analizi”, Diplomatik Gündem, Vol:2(17), p. 2-11.

- Karluk, 2015. “Avrasya Gümrük Birliği ve Türkiye’nin Üyeliği”, Uluslararası Avrasya Ekonomileri Konferans1, SESSION 7B: Bölgesel Ekonomiler III, p. 337-344.

- Ozinian, 2013. “Türkiye-Ermenistan Ticaretine Genel Bakış ve Olası İşbirliklerinin Geliştirilmesi”, TurkishArmenian Bussiness Development Council.

- Ö̈zer, 2009. “Avrupa Birliğine Tam Üyeliğin Esiğinde Türkiye”, Yönetim Ve Ekonomi, Vol:16(1), p. 89-105.

- Ö̈zsan, 2015., “Avrupa Birliği’ndeki Ekonomik Yavaşlamanın Türkiye’nin Sektörel İhracatı Üzerindeki Etkisi”, Kalkınma Bakanlığı Ekonomi Çalışma Tebliğleri Serisi, Vol: 2015/2, p. 1.

- Sülün, 2015. “Avrasya Ekonomik Birliği”, İzmir Ticaret Odas1, http://izto.org.tr/demo_betanix/uploads/cms/yonetim.ieu.edu.tr/6025_1438764630.pdf

- SSahin, 2008. “Avrupa Birliğinde Demografik Dönüşümler Ve Türk Nüfusun Geleceği”, TSA Dergisi, Vol:2, p. 187-205.

- SŞen, 2014. “Adaylık Sürecinde AB ve Türkiye'nin Nüfus Yapısı Açısından Karşılaştırılması”, HAK-İŞ Uluslararası Emek ve Toplum Dergisi, Vol:3(7), p.120-145.

- Turkish Statistical Institute, 2016. http://www.tuik.gov.tr/PreTablo.do?alt_id=1046

- Türkiye Cumhuriyeti Dışişleri Bakanlığı, 2016. http://www.mfa.gov.tr/default.tr.mfa

- United Nations, Population Statistics of Eurasia Region, 2016. http://unstats.un.org/unsd/databases.htm

- Uysal, 2001. “Türkiye - Avrupa Birliği İlişkilerinin Tarihsel Süreci ve Son Gelişmeler”, Akdeniz I.I. B.F. Dergisi, Vol:1, p. 140-153.

- Yalçınkaya, Çılbant and Özçalık, 2009. “Avrupa Birliği Sürecinde Türk İmalat Sanayi Dış Ticaretinin Rekabet Gücü: 1989-2009 Dönemi VAR Analizi”, Yönetim ve Ekonomi, Vol:16(1), p. 115-137.

- World Bank, 2016. http://databank.worldbank.org/data/download/GDP.pdf

- Zengin, 2015. “Türkiye Ve Rusya Federasyonu Ticari İlişkileri”, Avrasya İncelemeleri Dergisi (AVID), Vol:I4(1), p. 61-103. 